\title{
ICHIMOKU KINKO HYO: KEUNIKAN DAN PENERAPANNYA DALAM STRATEGI PERDAGANGAN VALUTA ASING (STUDI KASUS PADA PERGERAKAN USD/JPY DAN EUR/USD)
}

\author{
Yoyo Cahyadi \\ Jurusan Akuntansi dan Keuangan, Fakultas Ekonomi dan Komunikasi, \\ Universitas Bina Nusantara \\ Jl. K.H. Syahdan No. 9, Palmerah, Jakarta Barat 11480 \\ ycahyadi@binus.edu
}

\begin{abstract}
Ichimoku Kinko Hyo is a technical analysis tool that can be used to predict the movement of a currency. Ichimoku Kinko Hyo has five components or indicators, they are Tenkan Sen (or Conversion Line), Kijun Sen (or Base Line), Chikou Span (or Lagging Span), Senkou Span A and Senkou Span B. This paper discusses the application of Ichimoku Kinko Hyo in predicting the movement of USD/JPY and EUR/USD. Daily and hourly chart have been used to conduct the analysis. The observation shows that Ichimoku Kinko Hyo relatively easier to be applied in daily chart. Ichimoku Kinko Hyo can give a prediction whether a currency pair will move in a trend or consolidation.
\end{abstract}

Keywords: Ichimoku Kinko Hyo, technical analysis, foreign exchange

\begin{abstract}
ABSTRAK
Ichimoku Kinko Hyo merupakan alat analisis teknikal yang dapat digunakan untuk memprediksi pergerakan mata uang. Ichimoku Kinko Hyo mempunyai lima komponen atau indikator yaitu Tenkan Sen (atau Conversion Line), Kijun Sen (atau Base Line), Chikou Span (atau Lagging Span), Senkou Span A dan Senkou Span B. Dalam tulisan ini studi kasus dilakukan terhadap pasangan mata uang USD/JPY dan EUR/USD. Grafik yang digunakan adalah grafik harian dan grafik per jam. Dari hasil pengamatan, terlihat bahwa Ichimoku Kinko Hyo relatif lebih mudah diterapkan pada grafik harian. Ichimoku Kinko Hyo dapat memberikan petunjuk apakah pergerakan suatu pasangan mata uang dalam kondisi tren tertentu atau konsolidasi.
\end{abstract}

Kata kunci: Ichimoku Kinko Hyo, analisis teknikal, valuta asing 


\section{PENDAHULUAN}

Perkembangan dunia investasi telah melahirkan beragam cara analisis mulai dari yang sederhana hingga yang kompleks. Masing-masing cara analisis mempunyai keunggulan dan kekurangannya masing-masing sehingga tidak ada satupun yang dapat dianggap paling unggul dan dapat diterapkan pada semua situasi. Kondisi demikian membuat cara trading dari setiap orang yang berkecimpung dalam dunia investasi berbeda-beda karena banyak dipengaruhi oleh cara analisis yang digunakannya. Dari sekian banyak cara analisis yang digunakan, biasanya para penggunanya membagi menjadi dua jenis yaitu analisis fundamental (fundamental analysis) dan analisis teknik (technical analysis). Kedua analisis tersebut dapat digunakan secara terpisah maupun bersama-sama, bergantung pada tujuannya. Walaupun demikian biasanya para trader ataupun investor seringkali memiliki preferensi untuk lebih menitikberatkan salah satu analisis dibandingkan yang lain.

Analisis fundamental lebih banyak menekankan pada analisis atas berbagai hal yang mempengaruhi kondisi suatu negara (misalnya tingkat inflasi, suku bunga, tingkat pertumbuhan ekonomi) atau sebuah perusahaan (misalnya rasio hutang terhadap modal, rasio lancar, rasio harga saham terhadap nilai buku). Analisis fundamental seringkali lebih banyak dipakai oleh para investor, yaitu mereka yang membeli instrumen investasi untuk tujuan jangka panjang dan tidak mencari keuntungan sesaat. Hal ini sesuai dengan sifat analisis fundamental yang biasanya hanya dapat dilakukan untuk periode tertentu saja karena data yang dibutuhkan tidak muncul setiap hari misalnya laporan keuangan perusahaan yang hanya muncul setiap 3 bulan sekali. Dampaknya pun biasanya relatif lebih panjang dibandingkan dengan analisis teknikal.

Sedangkan analisis teknikal dilakukan dengan cara melakukan analisis terhadap pola pergerakan harga yang telah terjadi sebelumnya. Analisis jenis ini biasanya dipakai oleh para trader, yaitu mereka yang memperdagangkan instrumen investasi untuk jangka waktu yang relatif lebih pendek dibandingkan dengan investor. Analisis teknikal dapat digunakan untuk menganalisis data pergerakan suatu instrumen dalam berbagai jangka waktu mulai dari yang sangat pendek seperti setiap detik hingga jangka panjang seperti bulanan atau bahkan tahunan. Dengan demikian para trader dapat menganalisis untuk mencari kesempatan mendapatkan keuntungan jangka pendek melalui jual beli instrumen investasi. Walaupun analisis teknikal terkesan sederhana karena hanya menganalisis pergerakan harga instrumen yang sudah terjadi, namun dalam perkembangannya ternyata bermunculan banyak sekali variasi metode dengan berbagai pendekatan. Masing-masing memiliki keunggulan dan kelemahan serta seringkali tidak dapat diterapkan untuk semua situasi perdagangan. Berbagai pilihan tersebut juga membuat para trader dapat menggunakan banyak kombinasi analisis teknikal untuk membuat satu kesimpulan. Sayangnya tidak semua analisis teknikal dapat dikombinasikan begitu saja dalam menganalisis suatu instrumen investasi mengingat sifatnya yang berbeda-beda.

Salah satu analisis teknikal yang menarik untuk ditelaah lebih jauh adalah Ichimoku Kinko Hyo. Analisis teknikal yang berasal dari Jepang ini dapat dikatakan merupakan pengembangan dari teknik candlestick. Analisis tersebut menarik karena di dalamnya seakan merupakan kombinasi dari beberapa analisis teknikal yang ditampilkan sekaligus sehingga pengguna tidak perlu memilih kombinasi yang tepat. Namun tentunya jika pengguna masih merasa kurang, pengguna analisis tersebut masih dapat menambahkan kombinasi dengan analisis teknikal yang lain.

Ichimoku Kinko Hyo (atau sering hanya disebut Ichimoku) biasanya diterjemahkan secara bebas sebagai equilibrium at a glance atau keseimbangan sekilas. Teknik ini pertama kali dipublikasikan pada tahun 1968 oleh seorang wartawan bernama Goichi Hosoda yang melakukan pengembangan atas teknik analisis candlestick. Sebagai wartawan, dia menggunakan nama samaran "Ichimoku Sanjin" di mana karakter huruf kanji pertama dari namanya berarti "sekilas" dan karakter berikutnya berarti seorang yang berdiri di pegunungan. Dengan demikian nama tersebut memberikan nuansa atas sudut pandang dan kejelasan dari tipe grafik yang ditawarkannya (Elliot, 2007). 
Ichimoku Kinko Hyo seringkali juga disebut sebagai kumo chart atau grafik awan karena bentuknya yang mirip awan seperti terlihat pada Gambar 1. Bagi yang belum mengenal grafik ini akan melihatnya sebagai kumpulan berbagai garis yang saling tumpang tindih. Banyaknya garis dalam grafik tersebut karena Ichimoku Kinko Hyo mempunyai beberapa komponen atau indikator yang masing-masing mempunyai kegunaan yang berbeda. Komponen tersebut adalah Tenkan Sen (atau Conversion Line), Kijun Sen (atau Base Line), Chikou Span (atau Lagging Span), Senkou Span A dan Senkou Span B.

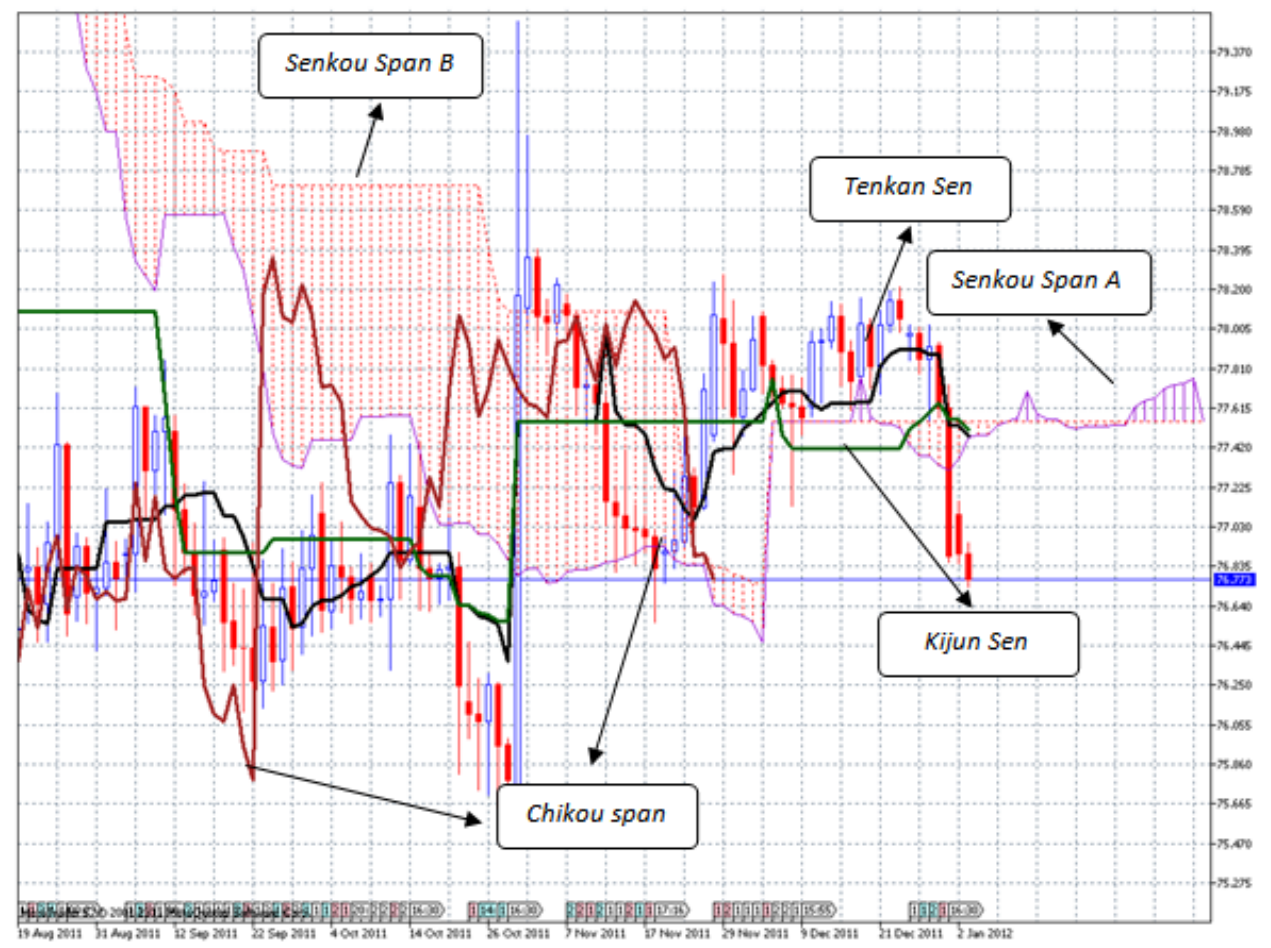

Gambar 1 Contoh Grafik Ichimoku Kinko Hyo

Sumber: Grafik pergerakan USD/JPY yang diambil dari software MetaTrader 5

Garis Tenkan Sen atau disebut juga Conversion Line dibentuk berdasarkan rumus perhitungan sebagai berikut:

$$
\frac{(\text { Highest High }+ \text { Lowest Low })}{2} \text { untuk } 9 \text { periode }
$$

Sekilas hal ini mirip dengan cara perhitungan untuk Simple Moving Average (SMA) tetapi penggunaan highest high dan lowest low di sini menunjukkan bahwa Ichimoku memperhitungkan volatilitas harian atau volatilitas dalam periode tersebut. Sembilan periode yang dimaksud di sini adalah apabila menggunakan grafik harian maka yang dihitung adalah 9 hari ke belakang, apabila menggunakan grafik per jam maka yang dihitung adalah 9 jam ke belakang.

Garis Kijun Sen atau disebut juga Base Line dibentuk dengan rumus perhitungan yang sama dengan Tenkan Sen tetapi dengan jangka waktu perhitungan lebih panjang sebagai berikut:

$$
\frac{(\text { Highest High }+ \text { Lowest Low })}{2} \text { untuk } 26 \text { periode }
$$


Duapuluh enam periode tersebut mewakili kurang lebih satu bulan perdagangan karena pada saat Ichimoku Kinko Hyo diperkenalkan jumlah hari kerja di Jepang adalah 6 (enam) hari dalam satu minggu. Sementara sembilan periode digunakan karena berdasarkan trial and error dan back testing diperoleh bahwa sembilan periode merupakan periode yang paling tepat untuk dikombinasikan dengan duapuluh enam periode (Elliot, 2007).

Pada saat ini penggunakan sembilan dan duapuluh enam periode memang seakan tidak mempunyai hubungan dengan periode apa pun tetapi para trader yang menggunakan Ichimoku Kinko Hyo masih menggunakan periode tersebut. Jumlah periode yang seakan kurang relevan dengan kondisi saat ini juga dipakai oleh komponen Ichimoku yang lain, sehingga apabila terdapat periode yang diganti maka kemungkinan periode yang lain pun harus diganti. Hal tersebut sangat tidak disarankan karena dapat mengubah seluruh konstruksi grafik yang berakibat kita tidak dapat memprediksi kemungkinan pergerakan harga yang disebabkan oleh keputusan para trader atau investor lain.

Seperti halnya penggunaan Moving Average, sinyal bullish (harga diperkirakan akan naik) diperoleh ketika garis dengan periode lebih pendek (dalam hal ini Tenkan Sen) memotong dari bawah ke atas garis dengan periode lebih panjang (dalam hal ini Kijun Sen). Sementara sinyal bearish (harga diperkirakan akan turun) diperoleh ketika garis Tenkan Sen memotong dari atas ke bawah garis Kijun Sen. Kegunaan lain dari garis Tenkan Sen dan Kijun Sen adalah sebagai garis support atau resistance. Garis Tenkan Sen cenderung lebih dekat ke grafik harga sehingga dalam kondisi pasar bearish, biasanya garis ini akan menjadi garis resistance pertama atau jangka pendek sedangkan garis Kijun Sen akan menjadi garis resistance kedua. Sebagai garis resistance kedua, Kijun Sen merupakan key resistance level. Kondisi sebaliknya berlaku untuk kondisi pasar bullish. Apabila harga bergerak menjauh dari Tenkan Sen maka besar kemungkinan harga akan berbalik mendekati Tenkan Sen karena pergerakan harga telah menyimpang jauh dari ekuilibrium (Patel, 2010).

Kemiringan (slope) dari garis Tenkan Sen dan Kijun Sen juga memperlihatkan kuat tidaknya sebuah tren yang terbentuk. Semakin tinggi sudut kemiringan garis tersebut maka semakin kuat tren tersebut akan berlanjut. Menurut Elliot, sudut kemiringan yang ideal untuk Kijun Sen adalah antara 33 sampai dengan 45 derajat (Elliot, 2007).

Garis ketiga adalah Chikou Span atau disebut juga Lagging Span. Garis ini dibentuk dari grafik harga saat ini yang dimundurkan 26 periode. Seperti terlihat pada Gambar 1, garis Chikou Span sama persis seperti grafik harga. Garis ini menunjukkan momentum harga atau dengan kata lain garis tersebut menunjukkan apakah sebuah tren akan muncul atau tidak (Patel, 2010).

Dua indikator atau garis berikutnya adalah Senkou Span A (atau disebut Leading Span A) dan Senkou Span B (atau disebut Leading Span B). Kedua garis tersebut membentuk Kumo atau awan dengan cara mengisi atau mewarnai area di antara kedua garis tersebut.

Senkou Span A dibentuk berdasarkan perhitungan sebagai berikut:

$$
\frac{(\text { Tenkan Sen }+ \text { Kijun Sen })}{2} \text { dimajukan untuk } 26 \text { periode }
$$

Maksud dari kalimat “dimajukan untuk 26 periode” adalah misalnya pada grafik harian, nilai Tenkan Sen dan Kijun Sen pada hari ini akan digunakan untuk menghitung titik Senkou Span pada hari ke-26 dari sekarang.

Indikator terakhir yaitu Senkou Span B yang akan digunakan bersamaan dengan Senkou Span $A$ dibentuk berdasarkan perhitungan sebagai berikut: 


\section{$\frac{(\text { Highest High }+ \text { Lowest Low })}{2}$ selama 52 periode dan dimajukan untuk 26 periode}

Dilihat dari rumus perhitungan tersebut terlihat bahwa Senkou Span B memperhitungkan volatilitas selama jangka waktu yang cukup panjang, bahkan jika menggunakan grafik mingguan maka akan diperhitungkan volatilitas selama 52 minggu atau 1 tahun terakhir. Ini merupakan garis yang menggunakan periode paling panjang dibandingkan dengan komponen Ichimoku yang lain. Sama juga dengan Senkou Span A, pada grafik harian hasil perhitungan pada hari ini akan digunakan untuk menentukan titik Senkou Span B pada hari ke-26. Logika di balik penggunaan jangka waktu 26 periode ke depan adalah bahwa harga saat ini dapat mempengaruhi pergerakan harga di masa depan.

Pembentukan Senkou Span A dan Senkou Span B yang ditarik 26 hari ke depan membuat terbentuk Kumo di masa depan sehingga terdapat 2 Kumo yaitu Kumo saat ini (current Kumo) dan Kumo masa depan (future Kumo). Kedua macam Kumo tersebut dapat dimanfaatkan karena masingmasing dapat memberikan informasi. Menurut Patel (2010) informasi yang dapat diperoleh dari current Kumo dan future Kumo sebagai berikut:

Tabel 1 Manfaat Current Kumo

\begin{tabular}{ll}
\hline \multicolumn{1}{c}{ Sentimen } & \multicolumn{1}{c}{ Kondisi } \\
\hline Bullish & Harga di atas Kumo \\
Bearish & Harga di bawah Kumo \\
Consolidation & Harga di dalam Kumo \\
\hline
\end{tabular}

Tabel 2 Manfaat Future Kumo

\begin{tabular}{ll}
\hline \multicolumn{1}{c}{ Sentimen } & \multicolumn{1}{c}{ Kondisi } \\
\hline Bullish & Senkou A di atas Senkou B \\
Bearish & Senkou A di bawah Senkou B \\
Consolidation & Senkou A sama dengan Senkou B \\
\hline
\end{tabular}

Dengan berbagai karakteristik yang cukup kompleks tersebut, sangat menarik untuk melihat apakah Ichimoku Kinko Hyo dapat memprediksi pergerakan berbagai valuta asing yang notabene mempunyai karakteristik berbeda-beda. Valuta asing yang akan dibahas dalam tulisan ini adalah USD/JPY dan EUR/USD yang merupakan dua dari mata uang major currencies yang sering diperdagangkan di pasar global.

Khusus untuk USD/JPY, diperkirakan banyak trader valuta asing yang menggunakan teknik Ichimoku Kinko Hyo hingga saat ini karena teknik tersebut berasal dari Jepang. Seperti diketahui di kalangan para teknikal analis, sebuah analisis teknikal akan lebih efektif jika digunakan oleh semakin banyak orang karena setiap orang yang menggunakan teknik tersebut seolah-olah dapat berkomunikasi untuk membuat kesepakatan bersama mengenai kemungkinan pergerakan sebuah pasangan mata uang (currency pair). Selanjutnya akan dilihat keakuratan Ichimoku Kinko Hyo terhadap EUR/USD sebagai pembanding di luar USD/JPY.

Selain melihat keakuratan Ichimoku Kinko Hyo dalam memprediksi pergerakan valuta asing pada pergerakan harian, tulisan ini juga akan membahas kemungkinan penggunaan teknik tersebut pada grafik dengan jangka waktu lebih pendek yaitu grafik per jam (hourly). Penelaahan terhadap penggunaan grafik dengan jangka waktu lebih pendek didasari pemikiran bahwa sebenarnya Ichimoku Kinko Hyo awalnya diciptakan untuk melihat tren pergerakan harga secara menengah hingga jangka panjang. 


\section{METODE}

Metode penelitian yang dilakukan dalam tulisan ini adalah studi pustaka dan melakukan analisis grafik melalui software MetaTrader 5. Bahan-bahan penelitian diperoleh dari buku-buku seputar topik Ichimoku Kinko Hyo. Gambar grafik Ichimoku Kinko Hyo yang digunakan untuk melihat bagaimana penerapan analisis teknikal tersebut pada instumen keuangan/investasi diperoleh dari software MetaTrader 5.

Pada penelitian ini dilakukan back testing atas analisis teknikal Ichimoku Kinko Hyo untuk melihat sejauh mana penerapannya dalam menganalisis pergerakan harga valuta asing di masa lalu, khususnya untuk pasangan mata uang USD/JPY dan EUR/USD. Backtesting dilakukan terhadap pergerakan USD/JPY dan EUR/USD dalam grafik harian selama 3 tahun yaitu tahun 2009 sampai dengan 2011 dan grafik per jam dari tanggal 6-20 Juli 2011 (untuk USD/JPY), 1-15 Maret 2011 (untuk EUR USD) dan 1-15 Desember 2011 (untuk USD/JPY dan EUR/USD). USD/JPY dipilih karena sesuai dengan asal Ichimoku Kinko Hyo yaitu dari Jepang. Namun tidak berarti bahwa teknik analisis ini tidak dapat digunakan dalam instrumen investasi atau keuangan yang lain sehingga pengamatan juga dilakukan terhadap EUR/USD sebagai pembanding. Grafik yang digunakan lebih difokuskan pada kerangka waktu harian (daily chart) karena Ichimoku Kinko Hyo sebenarnya merupakan teknik yang diciptakan untuk melihat tren pergerakan harga dalam jangka menengah dan panjang. Alasan lain karena grafik harian lebih umum dipakai untuk analisis sehingga akan memudahkan pemahaman.

\section{HASIL DAN PEMBAHASAN}

Salah satu keunikan Ichimoku Kinko Hyo adalah lima indikator atau garis dari komponennya memberikan gambaran kondisi harga pada masa lampau (yang ditunjukkan melalui indikator Chikou Span), masa sekarang (yang ditunjukkan melalui indikator Tenkan Sen dan Kijun Sen), dan masa depan (yang ditunjukkan melalui indikator Senkou Span A dan Senkou Span B). Hal tersebut membuat Ichimoku Kinko Hyo berbeda dengan analisis teknikal yang lain. Keunikan lain adalah adanya informasi major support atau resistance level. Informasi tersebut sangat berguna untuk menentukan apakah sebuah tren masih berlangsung dan pada level harga berapakah seorang trader dapat memasang entry atau exit level.

Ichimoku Kinko Hyo dengan segala keunikannya tersebut terlihat sangat cocok untuk digunakan dalam menentukan strategi perdagangan valuta asing. Sifat berdagangan valuta asing yang mendunia, 24 jam sehari dari Senin sampai Jumat (bahkan Sabtu pagi untuk wilayah waktu di Indonesia karena perbedaan waktu antara Indonesia dan Amerika Serikat) membuat para trader sangat sulit untuk terus menerus mengikuti pergerakan valuta asing menit demi menit. Setiap valuta asing selalu mempunyai karakteristik yang berbeda-beda karena biasanya sangat dipengaruhi oleh kebijakan negara yang bersangkutan, karakteristik perekonomiannya dan likuiditas valuta tersebut di pasar global. Perdagangan valuta asing juga dipengaruhi oleh kondisi perekonomian global dan sentimen para pemainnya, baik itu para investor maupun para trader valuta asing.

\section{Ichimoku Kinko Hyo pada Pergerakan USD/JPY}

Japanese Yen atau disingkat JPY merupakan salah satu mata uang yang banyak diperdagangkan dipasar global dan sering menjadi alat investasi bagi para investor karena suku bunganya yang sangat rendah. Pada tulisan ini akan dibahas pasangan mata uang USD/JPY yaitu pergerakan mata uang USD terhadap JPY. 

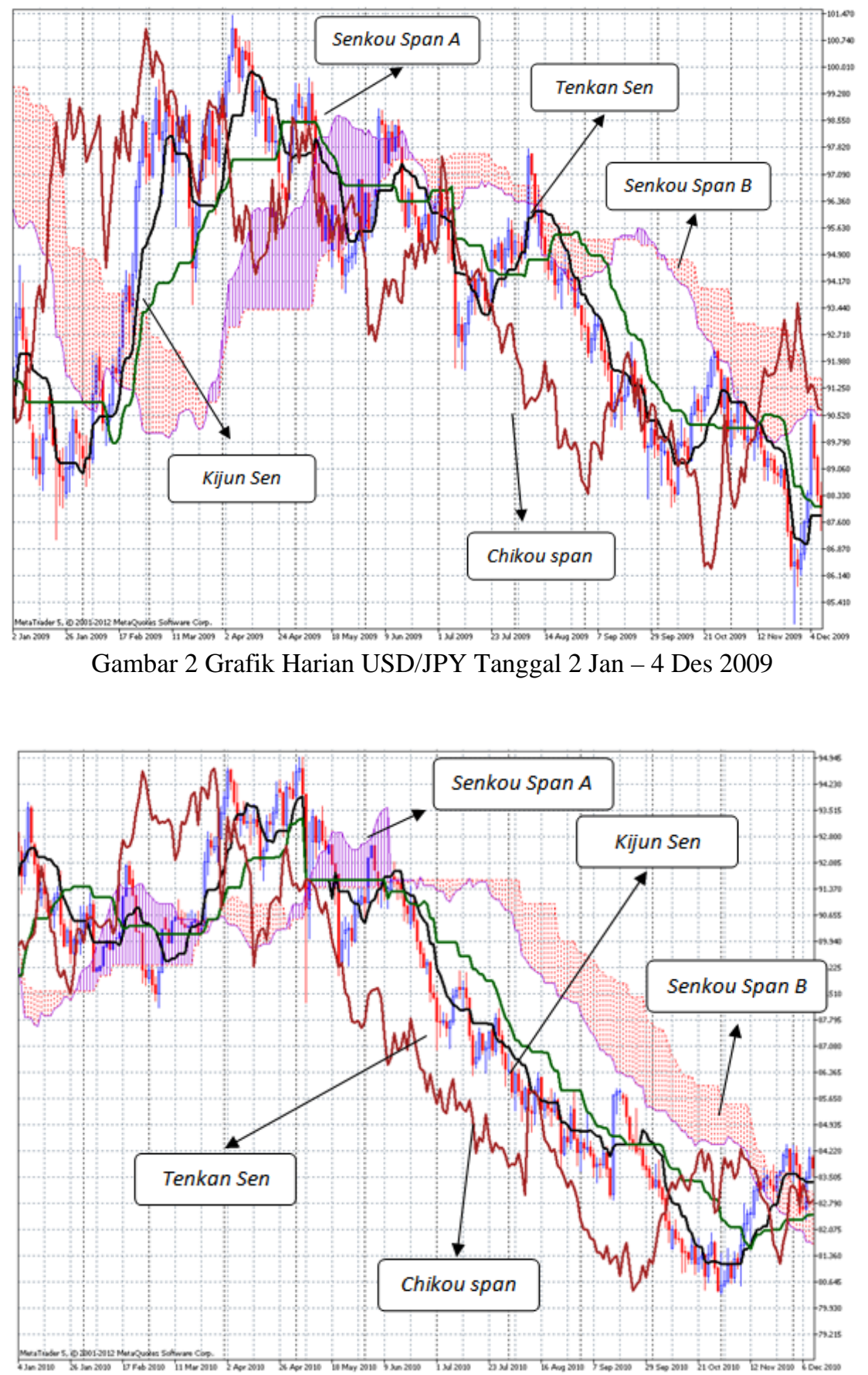

Gambar 3 Grafik Harian USD/JPY Tanggal 4 Jan - 6 Des 2010 


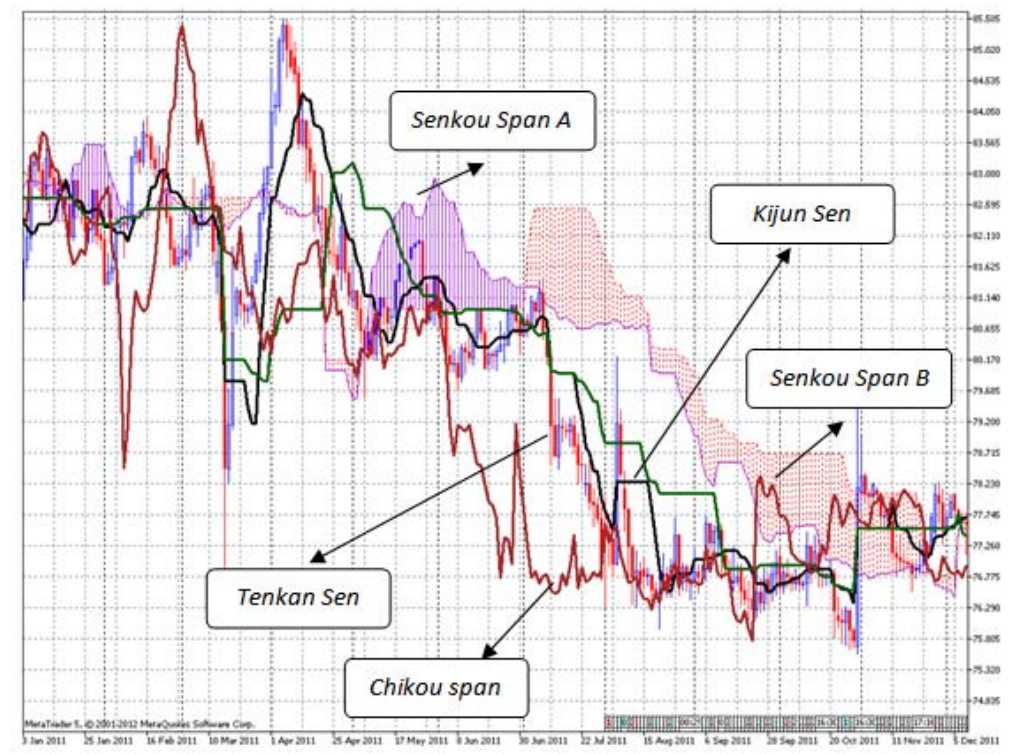

Gambar 4 Grafik Harian USD/JPY Tanggal 3 Jan - 5 Des 2011

Pada gambar 2 terlihat di awal Februari 2009 bahwa garis Tenkan Sen memotong garis Kijun Sen dari bawah yang menunjukkan sinyal bullish. Pada tanggal 17 Februari 2009 sinyal tersebut semakin dikuatkan oleh garis Chikou Span yang telah memotong grafik harga dari bawah pada 26 hari sebelum tanggal tersebut. Jika ditarik 26 hari ke depan dari tanggal tersebut terlihat bahwa Senkou Span A mulai berbalik di atas Senkou Span B yang berarti Future Kumo telah memberikan sinyal bullish juga walaupun Current Kumo masih memberikan sentimen konsolidasi karena grafik harga berada di dalam Kumo. Pada titik setelah perpotongan Tenkan Sen dan Kijun Sen sampai dengan tanggal 17 Februari 2009 grafik harga selalu berada di atas kedua garis tersebut yang telah menjadi garis support. Sejak tanggal tersebut terlihat juga bahwa sudut kemiringan garis Tenkan Sen dan Kijun Sen berada di kisaran 45 derajat atau lebih yang menunjukkan kuatnya tren yang terbentuk.

Pada gambar 3 terlihat Ichimoku Kinko Hyo memberikan petunjuk yang jelas ketika terjadi tren penurunan USD/JPY yang terjadi dari bulan Juni sampai dengan Oktober 2010. Jika dilihat pada posisi 26 hari sebelum awal Juni 2010 terlihat bahwa posisi Chikou Span telah berada di bagian bawah grafik harga dan kondisi penurunan harga telah dimulai dari sejak awal Mei 2010. Namun grafik harga di awal Juni 2010 bergerak naik dan masuk di dalam current Kumo yang berarti konsolidasi. Konfirmasi bearish baru terlihat pada pertengahan Juni 2010 ketika grafik harga telah menembus Tenkan Sen dan Kijun Sen yang merupakan support level. Pada saat itu future Kumo juga telah menunjukkan posisi Senkou Span A di bawah Senkou Span B yang berarti bearish.

Pada gambar 4, menarik untuk mencermati Kumo pada sekitar bulan Februari 2011 dan April 2011, di mana banyak terlihat kondisi Senkou Span A sama dengan Senkou Span B. Dalam kondisi tersebut, jika dilihat sebagai future Kumo maka itu adalah indikasi adanya konsolidasi dan hal tersebut sesuai dengan kondisi pada awal Januari dan awal Maret 2011 di mana harga bergerak dalam trading range. Terlihat juga pada tanggal tersebut bawah garis Tenkan Sen dan Kijun Sen bergantian saling memotong dalam jangka waktu yang relatif singkat.

\section{Ichimoku Kinko Hyo pada Pergerakan EUR/USD}

Euro (atau disingkat EUR) sebagai mata uang tunggal di negara-negara yang tergabung dalam Eropa Bersatu, merupakan salah satu mata uang yang sering dipakai dalam perdagangan internasional. Mata uang ini juga sering digunakan sebagai alternatif cadangan devisa selain US Dollar. Pada bagian ini akan diulas analisis teknikal Ichimoku Kinko Hyo atas pergerakan EUR terhadap USD. 
Pada Gambar 5 terlihat terbentuknya tren bearish pendek sejak pertengahan Januari hingga akhir Februari 2009 dan tren bullish panjang yang dimulai dari sekitar awal Mei hingga awal Desember 2009. Dalam kedua tren tersebut, grafik harga lebih sering berada di bawah garis Tenkan Sen atau Kijun Sen (kondisi bearish) atau di atas kedua garis tersebut (kondisi bullish). Pada saat tingkat kemiringan Kijun Sen di kisaran 33 sampai dengan 45 derajat, grafik harga terlihat sulit menembus garis tersebut. Sedangkan pada pertengahan Maret sampai dengan April 2009 grafik harga banyak bergerak di dalam Kumo yang menunjukkan kondisi konsolidasi.

Pada Gambar 5, 6 dan 7 beberapa kali terlihat grafik harga berada cukup jauh dari Kumo ketika terbentuk tren yang kuat. Jika dikaitkan dengan current Kumo bahwa kondisi konsolidasi terjadi apabila harga berada di dalamnya, situasi tersebut memberikan petunjuk bahwa peluang konsolidasi relatif kecil sampai tertembusnya Tenkan Sen dan Kijun Sen. Dalam kondisi harga jauh dari Kumo, trader dapat memanfaatkannya dengan memasang entry level di sekitar Tenkan Sen atau Kijun Sen dan stop loss level pada titik jika kedua garis tersebut tertembus.

Pada gambar 6 dan 7, Ichimoku Kinko Hyo terlihat masih konsisten memberikan petunjuk seperti yang dijabarkan pada analisis dari gambar sebelumnya. Situasi konsolidasi terlihat pada gambar 7 mulai dari Juni hingga Agustus 2011. Kondisi Kijun Sen yang datar atau flat dari sejak pertengahan Mei hingga Agustus 2011 mendukung hal tersebut. Namun berbaliknya sebuah tren tidak harus didahului dengan kondisi mendatarnya Kijun Sen selama beberapa waktu. Seperti terlihat pada gambar 6, menjelang akhir Juni 2010 tren berbalik dari bearish menjadi bullish. Pada situasi tersebut, Kijun Sen hanya sempat mendatar sebentar lalu langsung berpotongan dengan Tenkan Sen dan berbalik arah.

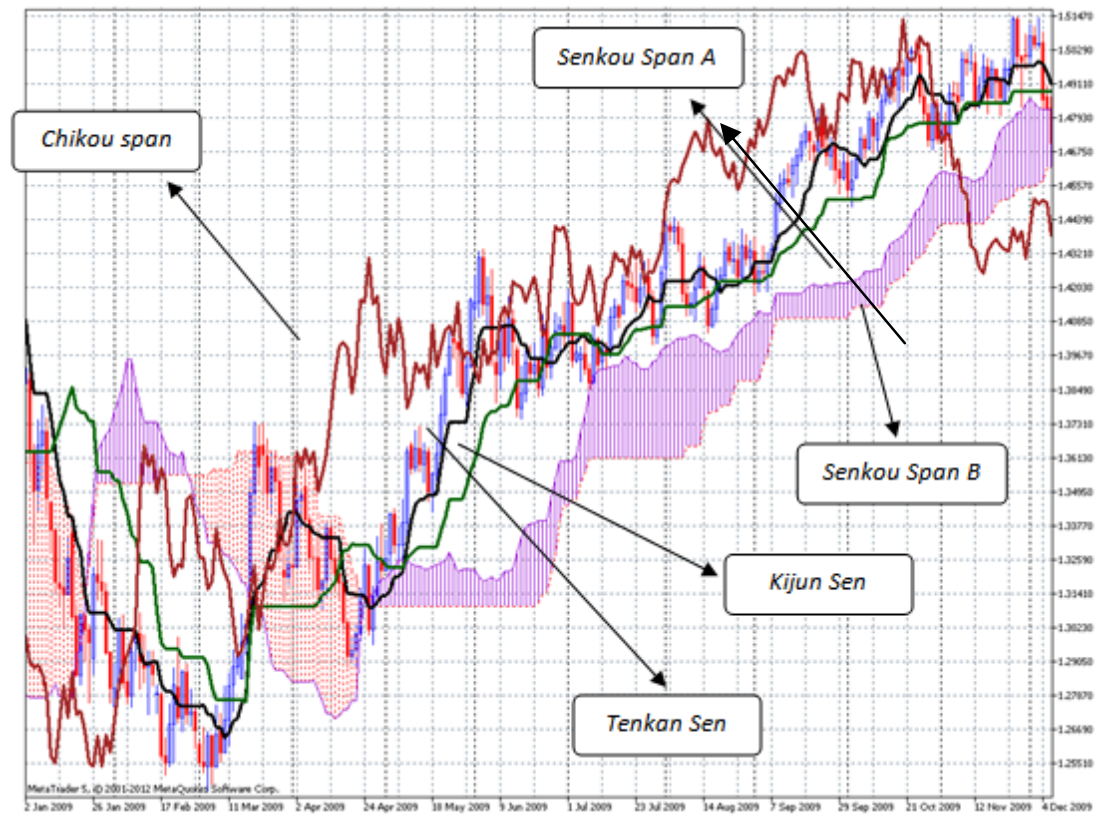

Gambar 5 Grafik Harian EUR/USD Tanggal 2 Jan - 4 Des 2009 


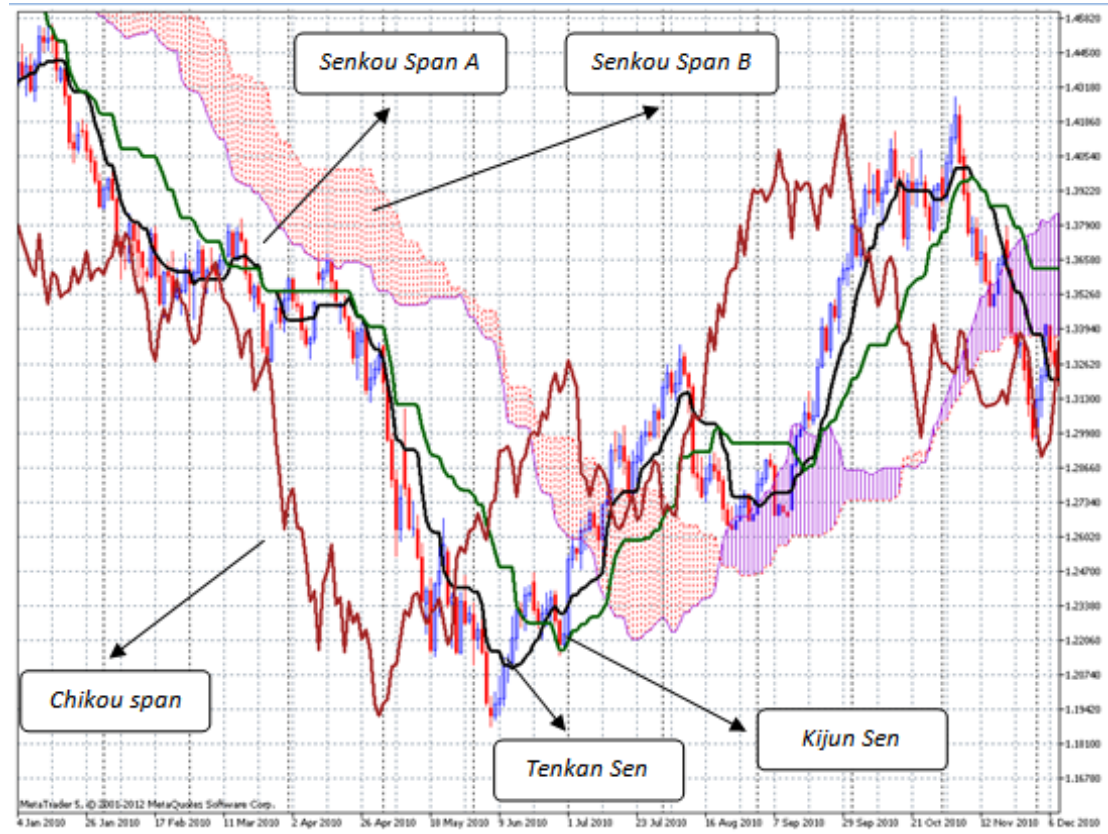

Gambar 6 Grafik Harian EUR/USD Tanggal 4 Jan - 6 Des 2010

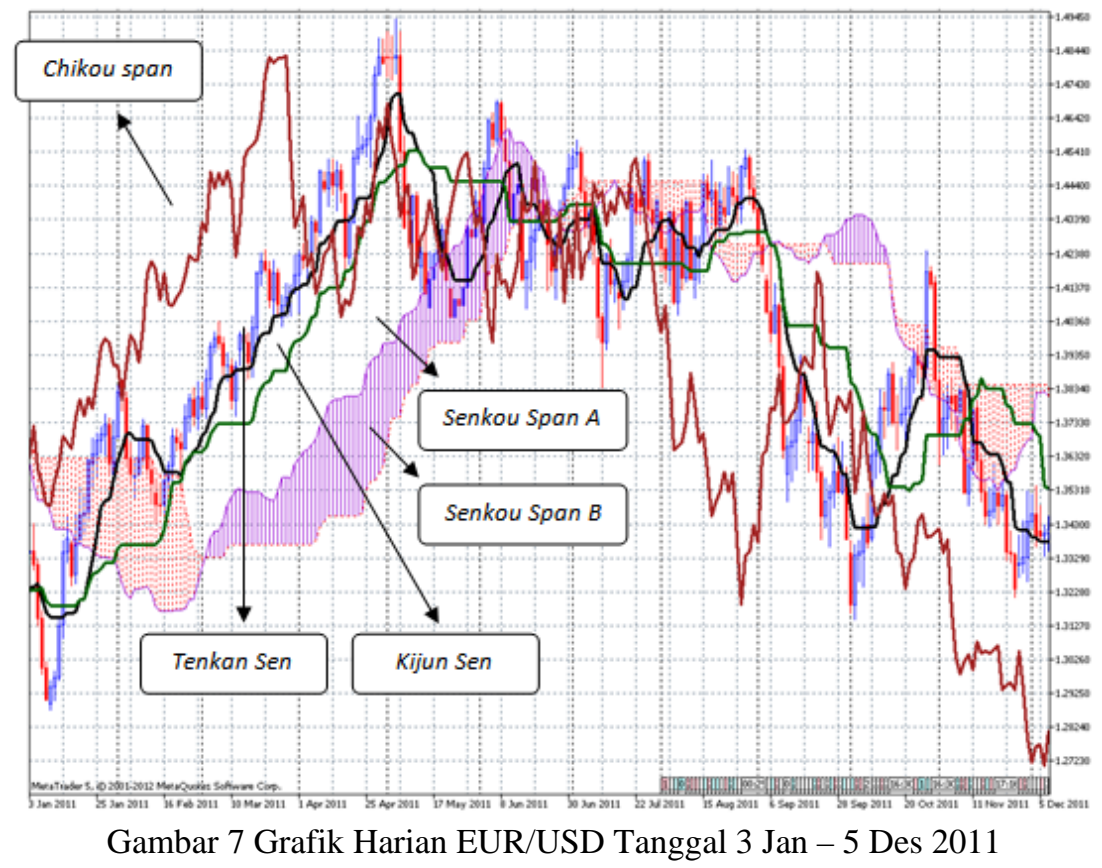




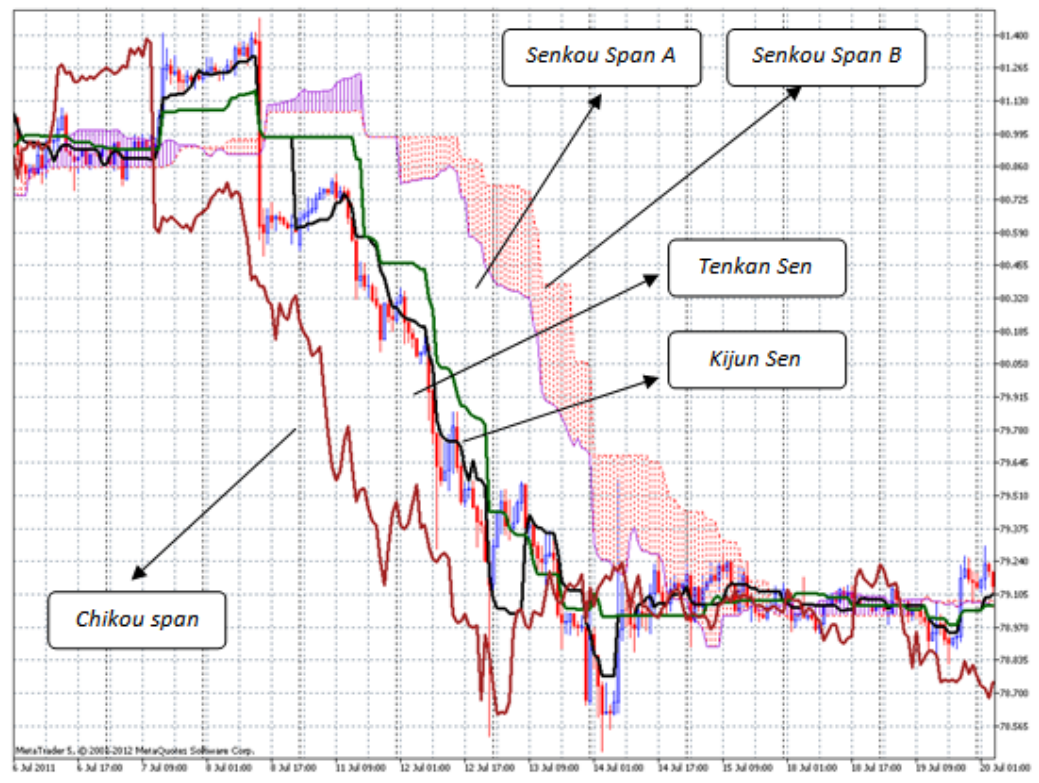

Gambar 8 Grafik per Jam USD/JPY Tanggal 6 - 20 Juli 2011

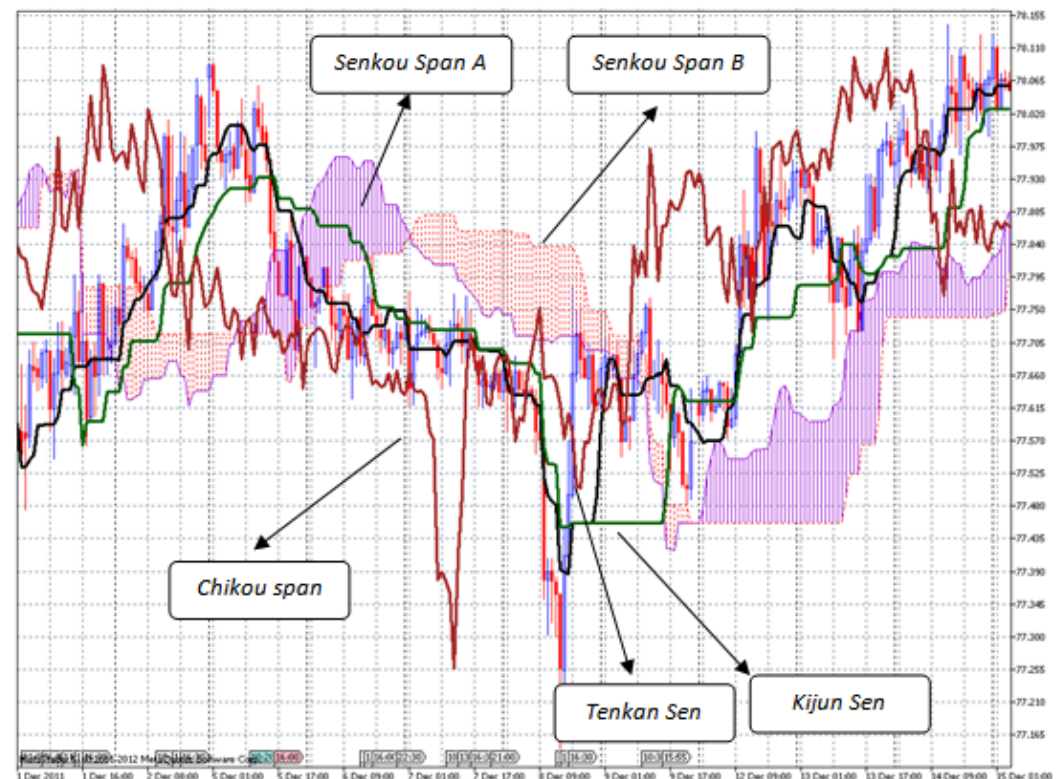

Gambar 9 Grafik per Jam USD/JPY Tanggal 1 - 15 Des 2011 


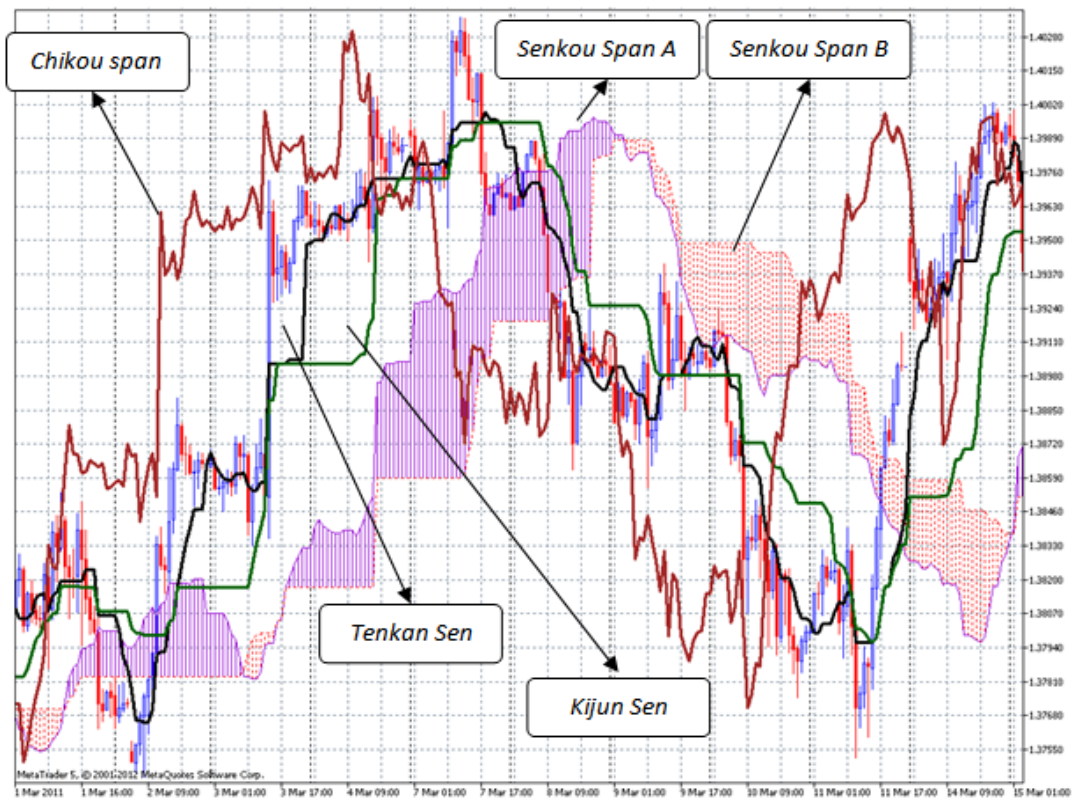

Gambar 10 Grafik per Jam EUR/USD Tanggal 1 - 15 Maret 2011

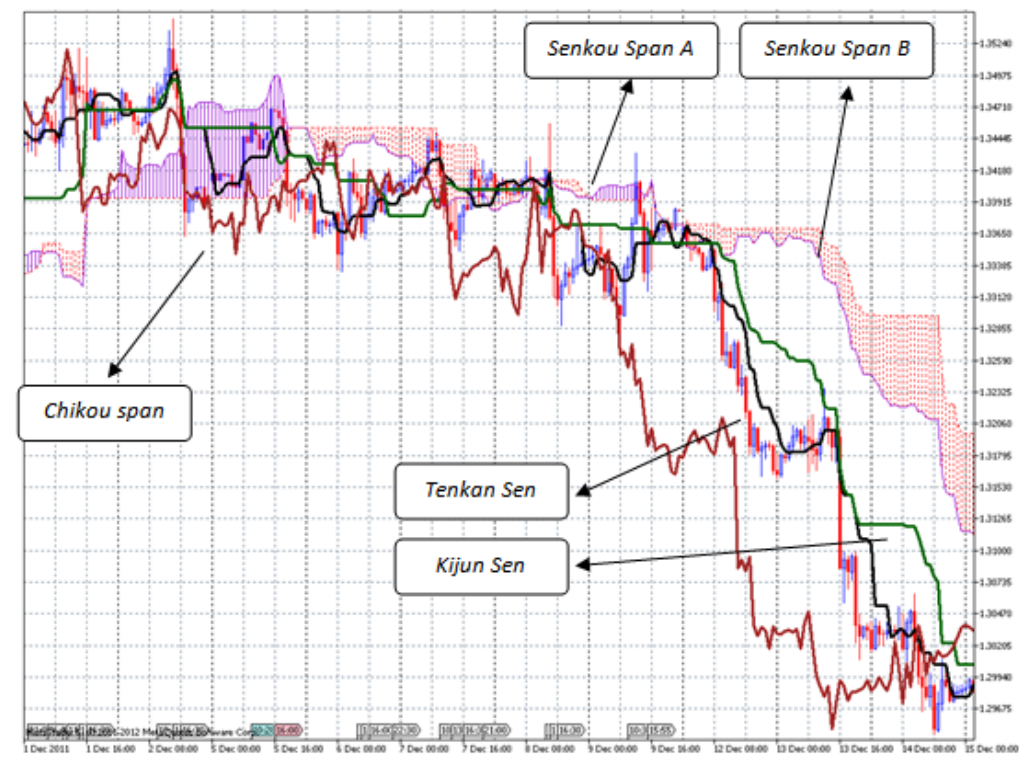

Gambar 11 Grafik per Jam EUR/USD Tanggal 1 - 15 Des 2011

Pada gambar 8 dan 9 dapat dilihat penerapan Ichimoku Kinko Hyo pada grafik harian USD/JPY. Terlihat bahwa komponen Ichimoku Kinko Hyo lebih banyak memberikan informasi pada saat pasar bergerak dalam tren tertentu, seperti terlihat di gambar 8 pada situasi tanggal 11 Juli 2011 pukul 09.00 sampai dengan 14 Juli 2011 pukul 01.00. Jika dibandingkan dengan gambar 4, memang terlihat bahwa sedang terjadi tren pada grafik harian yaitu bearish pada tanggal-tanggal tersebut. Pada gambar 8 maupun 9 terlihat bahwa dalam kondisi pasar konsolidasi, indikator pada Ichimoku Kinko Hyo relatif sulit dibaca apalagi jika Tenkan Sen dan Kijun Sen saling bertukar posisi dengan cepat. 
Gambar 10 dan 11 menunjukkan penerapan Ichimoku Kinko Hyo pada grafik harian EUR/USD. Hal yang sama terlihat juga pada kedua grafik tersebut bahwa indikator Ichimoku Kinko Hyo relatif lebih mudah dibaca saat kondisi pasar sedang dalam tren tertentu dan relatif sulit ketika pasar sedang dalam posisi konsolidasi.

Jika kondisi indikator Ichimoku Kinko Hyo pada saat konsolidasi dalam grafik per jam dibandingkan dengan kondisinya dalam grafik harian, terlihat bahwa indikator-indikator tersebut lebih rumit pada grafik per jam. Situasi ini muncul karena dalam grafik per jam pergerakan grafik harga lebih cepat sehingga jika terjadi situasi konsolidasi garis Tenkan Sen dan Kijun Sen misalnya dapat bertukar posisi dengan cepat. Hal ini sejalan dengan kondisi awal diciptakannya Ichimoku Kinko Hyo yang memang lebih ditujukan untuk melihat tren jangka menengah dan panjang.

Namun kondisi indikator Ichimoku Kinko Hyo yang lebih rumit pada grafik per jam saat konsolidasi tidak berarti bahwa teknik analisis tersebut tidak dapat digunakan dalam grafik per jam. Paling tidak terdapat dua kondisi di mana Ichimoku Kinko Hyo masih dapat digunakan pada grafik per jam yaitu saat ingin melakukan intraday trading ketika pasar sedang dalam tren atau mencari entry point jika ingin melakukan trading harian. Garis Tenkan Sen dan Kijun Sen pada grafik per jam dapat digunakan sebagai acuan entry point untuk melakukan trading harian karena kedua garis tersebut berbeda dengan garis yang terbentuk pada grafik harian.

\section{PENUTUP}

Ichimoku Kinko Hyo dapat menunjukkan apakah pergerakan suatu pasangan mata uang dalam kondisi tren tertentu atau konsolidasi. Namun dalam penggunaannya, Ichimoku Kinko Hyo lebih sesuai digunakan ketika kondisi pasar sedang membentuk tren tertentu. Pada saat kondisi pasar sedang dalam tren, garis Tenkan Sen dan Kijun Sen dapat digunakan sebagai acuan tingkat support atau resistance. Ichimoku Kinko Hyo sesuai digunakan untuk memprediksi pergerakan harga valuta asing khususnya USD/JPY dan EUR/USD seperti yang dijabarkan dalam tulisan ini. Ichimoku Kinko Hyo lebih cocok diterapkan dalam grafik harian. Penggunaan pada grafik per jam lebih mudah jika situasi pasar sedang dalam tren tertentu, namun relatif lebih sulit jika dalam kondisi konsolidasi. Ichimoku Kinko Hyo dapat digunakan pada grafik harian pada saat ingin melakukan intraday trading ketika pasar sedang dalam tren atau mencari entry point jika ingin melakukan trading harian. Penelitian lebih lanjut dapat dilakukan terhadap penggunaan Ichimoku Kinko Hyo untuk memprediksi pergerakan harga valuta lain (selain USD/JPY dan EUR/USD), harga saham dan juga harga komoditi. Penggunaan Ichimoku Kinko Hyo pada berbagai kerangka waktu juga dapat diteliti lebih lanjut untuk melihat kesesuaiannya pada masing-masing kerangka waktu.

\section{DAFTAR PUSTAKA}

Elliot, N. (2007). Ichimoku chart: An introduction to ichimoku kinko clouds. Cambridge: Hariman House.

Patel, M. (2010). Trading with ichimoku clouds: The essential guide to ichimoku kinko hyo technical analysis. New Jersey: John Wiley \& Sons. 